Review

\title{
Carbon-Based Catalysts for Biodiesel Production-A Review
}

\author{
Jack Clohessy and Witold Kwapinski * (D) \\ Department of Chemical Sciences, Bernal Institute, University of Limerick, V94 T9PX Limerick, Ireland; \\ 16171756@studentmail.ul.ie \\ * Correspondence: witold.kwapinski@ul.ie
}

Received: 29 December 2019; Accepted: 23 January 2020; Published: 31 January 2020

\begin{abstract}
In recent years, a new class of superior heterogeneous acid catalyst for biodiesel production has emerged. These catalysts offer advantages over their predecessors such as high surface area, elevated acid site density, enhanced catalyst activity, good operation stability and relevant economic affordability in an environmentally friendly frame. This review was concerned with carbon-based solid acid (CBAS) catalysts derived from both carbohydrate and pyrolysis products. A series of CBASs with various origins such as D-glucose, sucrose, starch, cellulose and vegetable oil asphalt, converted to char and sulphonated, have been explored as potential heterogeneous catalysts. Catalyst preparation and synthesis methods were briefly summarized. Catalyst characterization and performance for biofuels related reactions were elucidated, identifying potential research applications. Three catalysts in particular were identified as having potential for industrial application and requiring further research.
\end{abstract}

Keywords: heterogeneous acid catalyst; biofuel; transesterification; carbohydrate; biomass; biochar

\section{Introduction}

There has been a spike in interest in fossil fuel alternatives in recent years due to growing concerns regarding the environmental impact of fossil fuel usage. According to the report by the IPCC [1], human-induced global warming reached approximately $1{ }^{\circ} \mathrm{C}$ above pre industrial levels in 2017. Among these alternatives is biodiesel, a substitute for traditional petrochemical diesel, that is composed of fatty acid methyl esters (FAMEs) and can be used in diesel compression engines without modification [2,3]. Biodiesel is a favourable option to traditional diesel due to its non-toxic, biodegradable nature and its emission profile, which contains little to no sulphur dioxide and a reduced amount of $\mathrm{CO}$ and $\mathrm{CO}_{2}$ [4-7]. According to item four, article three of the renewable energy directive, it is a requirement by law for all EU member states to ensure that a minimum of $10 \%$ of the energy consumed in transport comes from renewable sources such as biodiesel by 2020. Under the Paris agreement, a new EU directive was established, setting the requirement for renewable energy use by 2030 at 32\% [8]. Currently, the production of biodiesel is more expensive than traditional diesel production but, as a result of the renewable energy directive, the demand for biodiesel as a fuel additive is rising $[9,10]$. Biodiesel consists of a mixture of $C_{12}-C_{14}$ fatty acid monoalkyl esters. The FAME present in biodiesel is produced commercially via two pathways, the transesterification of triglycerides (TGs) and the esterification of free fatty acids (FFAs) [10,11]. Transesterification takes place in the presence of a short-chain alcohol (usually methanol) and a catalyst, as schematically presented in Figure 1. Transesterification of TGs to FAMEs is a process with three consecutive steps. Firstly, diglycerides are formed from triglycerides, then monoglycerides and finally FAMEs are formed. Glycerol is produced as a by-product of the reaction [10,11]. The reaction produces 3 moles of FAME and 1 mole of glycerol for each mole of TG [11,12]. 
<smiles>[R]C(=O)OC([2H])C(OC([R])=O)C([2H])OC([R])=O</smiles>

TG

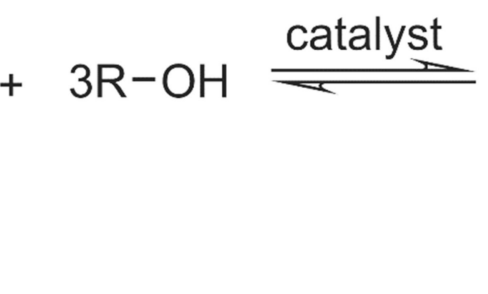

Alcohol<smiles></smiles>

FAME<smiles>OCC(O)O</smiles>

Glycerol

Figure 1. Transesterification of triglycerides.

The esterification of FFAs in the presence of a short-chain alcohol and a suitable catalyst is the second route for FAME production, presented in Figure 2.

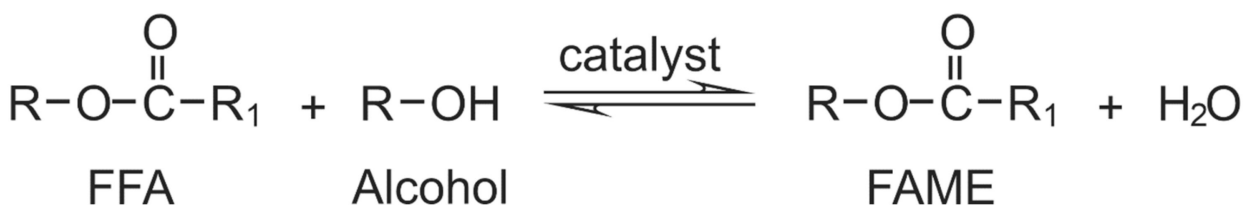

Figure 2. Esterification of free fatty acids.

Traditional biodiesel production methods utilise homogeneous base catalysis for the transesterification reaction, the reaction is carried out at atmospheric pressure and mild temperatures $\left(50-80^{\circ} \mathrm{C}\right)$ and an oil to alcohol ratio in the region of 5:1 [13,14]. While homogeneous base catalysis boasts a high yield of biodiesel, mild operating conditions and a fast reaction rate, there are several obstacles that prevent the process from being economically viable $[10,15,16]$.

Firstly, the homogeneous nature of the process means that the separation of the homogeneous base is difficult and requires an energy and cost intensive neutralisation and water-washing step [6,15]. Secondly, while liquid base catalysts catalyse the transesterification very well, the presence of FFAs presents a problem, as a saponification reaction will occur when FFAs are present in the feedstock for a liquid base catalysed reaction. The formation of soap inhibits the separation of the FAMEs, the water and the glycerol [6,17-20]. As a result, the oil feedstock for homogeneous base catalysis must be a virgin vegetable oil, with a very low FFA content $(<0.5 \mathrm{wt} . \%)$, or waste oils (such as cooking oil) must be pre-treated to lower the FFA content $[12,17,18]$. It is estimated that $70 \%-90 \%$ of the cost of biodiesel production is due to the cost of raw materials [12,21,22]. First-generation biodiesel production uses edible feedstock to produce FAMEs; while the FFA content is low, this process is uneconomical due to the competition for these oils with the food market $[11,23,24]$. Second-generation biodiesel production utilises lower-cost inedible feedstock or waste cooking oils, and these lower-grade plant oils and waste oils often have elevated FFA and water content, making homogeneous base catalysis an economically unfavourable process $[11,19]$.

Homogenous acid catalysis is insensitive to FFA content and has the potential to carry out simultaneous esterification and transesterification. Despite this distinct advantage, homogeneous acid catalysis presents the same separation issues as homogeneous base catalysis. As well as this, the rate of reaction for the transesterification process is much slower than homogeneous base catalysis, making the process economically challenging due to the increased energy requirements [2,25-31].

Heterogeneous catalysis using a solid base catalyst for the transesterification of TGs shares many of the same properties as the homogeneous base catalysis such as mild operating conditions, a fast rate of reaction and a high conversion $[28,29,32-34]$. However, heterogeneous base catalysis has a distinct 
advantage over the traditional homogeneous base catalysis. The heterogeneous nature of the reaction means that no separation is required and that the catalyst has the potential to be reused multiple times $[9,11,32]$. Similarly in heterogeneous case, the feedstock is required to have a FFA content below $0.5 \%$ as the by-products of the saponification reaction poisons the catalyst and prevents re-use [11,32]. Leaching of the base into the feedstock was also a commonly reported issue [35]. Due to the leaching, homogeneous catalysis was effectively occurring, which was problematic as a separation step was necessary $[19,36]$.

Heterogeneous acid catalysis is a promising alternative to conventional biodiesel production due to the simplistic and environmentally friendly nature of the process and the simultaneous promotion of both esterification and transesterification [37-39]. In particular, this study will focus on a branch of solid acid catalysts known as sulphonated carbon-based acid solids (CBASs). CBASs are formed from either carbohydrate or biomass precursors. The mechanism described by Okamura et al. [40], with a further stage suggested by Hara (2010) [41], was adapted by the authors in Figure 3. In the first stage (A) of catalyst production, the carbohydrate/biomass is carbonised, which leads to the removal of water from the molecules and (B) the dissociation of the $\mathrm{C}-\mathrm{O}-\mathrm{C}$ bond, forming polycyclic aromatic carbon sheets. The carbon sheets formed are then subjected to sulphonation $(\mathrm{C})$ with sulphuric acid; the acid sulphonates the aromatic rings, introducing $\mathrm{SO}_{3} \mathrm{H}, \mathrm{COOH}$ and $\mathrm{OH}$ groups at the edge of the carbon rings, forming the CBAS material that acts as a 3-D structure catalyst. During step (D), the carbonisation temperature is raised to $500{ }^{\circ} \mathrm{C}$ and larger polycyclic aromatic sheets are formed with the layered polycyclic aromatic rings, which reduce the amount of potential locations of sulphuric groups.

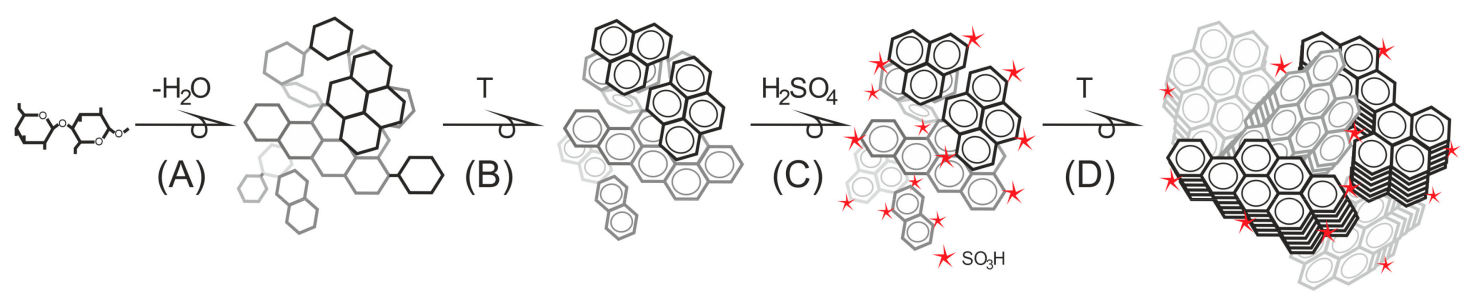

Figure 3. Mechanism of sulphonated carbon-based acid solid (CBAS) synthesis.

CBASs show high affinity for both the esterification and the transesterification reaction. They have been shown to have better activities for both the esterification of FFAs and the transesterification of TGs than commercially available solid acid catalysts such as sulphated zirconia and niobic acid [10,42]. CBASs can tolerate high FFA and water content meaning lower quality unrefined feedstock can be used such as waste cooking oil $[43,44]$. Solid acid catalysis demonstrates reliable re-usability, has been shown to be chemically inert and can be used to simultaneously carry out esterification and transesterification [11,41].

The characteristics that make a CBAS an effective catalyst for the production of biodiesel are strong Bronsted and Lewis acid sites, high acid site density, a hydrophobic surface, high pore volume and unique porosity $[10,11,45]$. This review will focus on the different types of CBASs currently being researched, preparation methods, and classification as catalysts and effectiveness in terms of both esterification and transesterification.

\section{Carbohydrate Precursors}

A novel branch of carbonaceous catalysts, formed by the incomplete carbonisation of carbohydrate sources such as D-glucose, sucrose, starch and cellulose followed by subsequent sulphonation has been shown to exhibit excellent catalytic activity for the esterification and transesterification reactions in biodiesel production [10].

Zong et al. [46] utilised D-glucose to prepare a CBAS to catalyse the esterification of oleic acid and subsequently waste cooking oil. D-glucose was incompletely carbonised at $400{ }^{\circ} \mathrm{C}$ for $15 \mathrm{~h}$ under $\mathrm{N}_{2}$ flow, following the carbonisation the material was ground to a powder before being heated to 150 
${ }^{\circ} \mathrm{C}$ in concentrated $\mathrm{H}_{2} \mathrm{SO}_{4}$ for a further $15 \mathrm{~h}$. The catalytic ability of this sulphonated sugar catalyst was compared to three typical solid acid catalysts, namely sulphated zirconia, niobic acid and amberlyst 15 resin. The reaction was carried out at $80^{\circ} \mathrm{C}$, with an alcohol to oil molar ratio of 10:1. The sugar catalyst demonstrated a higher catalytic activity than sulphated zirconia and Amberlyst 15. It was reflected in the yields of methyl oleate achieved by the various catalysts, presented in Table 1.

Table 1. Catalytic activity and methyl oleate yield (esterification) for various catalysts.

\begin{tabular}{|c|c|c|}
\hline Catalyst & Catalytic Activity $\mu \mathrm{mol} \mathrm{min}^{-1}$ & Yield of Methyl Oleate wt. $\%$ \\
\hline Sugar Catalyst & 67 & 95 \\
\hline Sulphated Zirconia & 21 & 85 \\
\hline Amberlyst 15 & 7 & 15 \\
\hline Niobic Acid & 1.5 & 6 \\
\hline
\end{tabular}

Niobic acid demonstrated little to no catalytic activity. Despite the larger BET surface area of the sulphated zirconia the increased number of acid sites in the sugar catalyst, lead to an improved catalytic ability. As part of their study, Zong and his team utilised the D-glucose catalyst to catalyse the conversion of waste oil with a high FFA content to biodiesel. Use of this type of oil is not possible applying traditional homogeneous base methods. The D-glucose catalyst achieved a yield of over $90 \mathrm{wt} . \%$, which was far greater than any of the typical commercial catalysts tested, compared in Figure 4 . The catalyst retained $93 \%$ of its catalytic activity following fifty successive uses demonstrating excellent reusability properties.

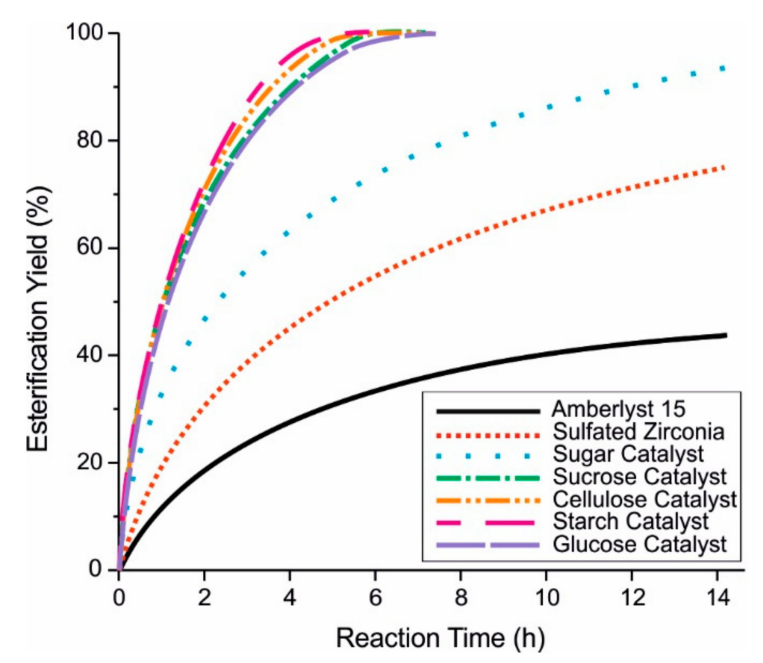

Figure 4. Esterification yield for carbohydrate-derived catalysts.

Nata et al. [39] demonstrated a one-step hydrothermal carbonisation of a glucose catalyst at $180^{\circ} \mathrm{C}$ for $4 \mathrm{~h}$. The resulting catalyst had an acidity of $1.99 \mathrm{mmol} \mathrm{g}^{-1}$ similar to the work of Zong et al. [46] Waste cooking oil (WCO), high in FFAs, was used to demonstrate the catalytic ability of the glucose catalyst. The reaction was carried out at $60{ }^{\circ} \mathrm{C}$ and a methanol:oil molar ratio of 20:1. A 95\% FFA conversion was achieved. The catalyst was reused and after five repeated uses, a 7\% increase in FFAs was observed indicating good reusability.

Hara [41] demonstrated the catalytic ability of sulphonated incompletely carbonised cellulose. The catalytic material was prepared in a similar way to the D-glucose catalyst by Zong et al. [46] The esterification of oleic acid to methyl oleate was used to demonstrate the catalytic ability of the sulphonated cellulose. The esterification reaction was carried out at $95{ }^{\circ} \mathrm{C}$. A yield of $99.9 \%$ was achieved after $4 \mathrm{~h}$, in six sequential runs the catalyst demonstrated excellent reusability for the esterification reaction, as presented in Figure 5. 


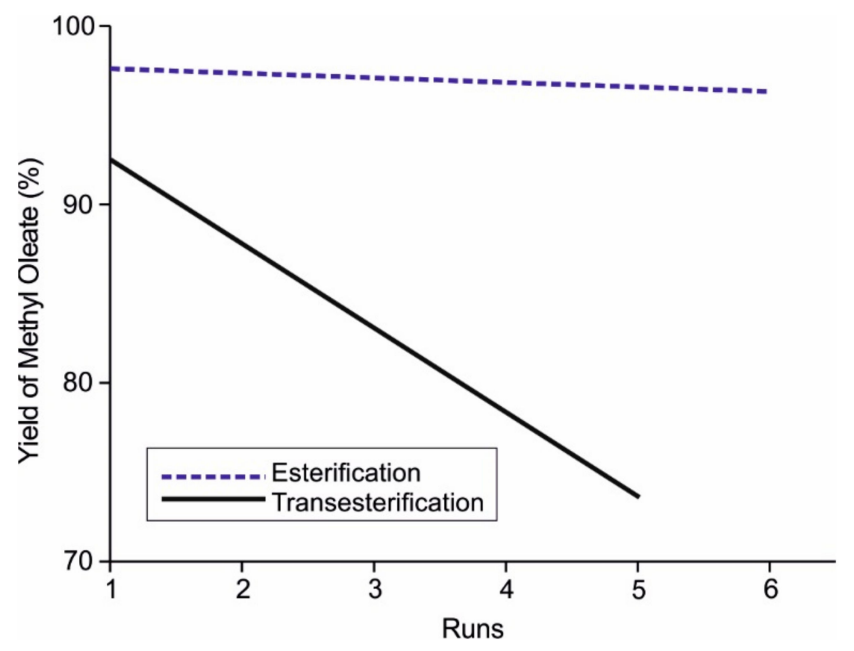

Figure 5. Reusability of cellulose-derived catalyst for esterification and transesterification reaction.

Hara [41] also investigated the ability of the catalyst to catalyse the transesterification reaction; the cellulose catalyst was used to catalyse the transesterification of triolein to methyl oleate in the presence of methanol. A conversion of $>98 \%$ was achieved; the catalyst demonstrated good reusability over five runs for the transesterification reaction, presented in Figure 5.

Lou et al. [10] prepared and compared four carbohydrate-derived catalysts from D-glucose, sucrose, cellulose and starch. The preparation method was as the same as that by Zong et al. [46] except carbonisation was carried out at $400{ }^{\circ} \mathrm{C}$ rather than $450{ }^{\circ} \mathrm{C}$. The esterification of oleic acid was used to evaluate the catalytic activity of the four catalysts. Each catalyst was added to a methanol oleic acid mixture, with a 10:1 molar ratio, and reacted at $80^{\circ} \mathrm{C}$. After $3 \mathrm{~h}$, the starch, cellulose, sucrose and D-glucose catalysts had achieved a conversion of $95 \%, 88 \%, 80 \%$ and $76 \%$, respectively. Figure 4 clearly indicates that the catalyst derived from starch was much more active for the esterification reaction than the other three catalysts. A yield of $95 \%$ was achieved in under $3 \mathrm{~h}$ whereas the cellulose, D-glucose and sucrose catalysts required $4-5 \mathrm{~h}$ to achieve a comparable yield.

For all four catalysts, the XRD pattern was typical of amorphous carbon. The starch-derived catalyst had the highest sulphur content, the highest acid site density and the highest contribution for $\mathrm{SO}_{3} \mathrm{H}$ to the acid site density. In terms of textural properties, the starch catalyst also possesses the most favourable properties, the largest surface area of the four carbohydrate-derived catalysts the largest average pore volume and average pore size (Table 2). The larger pore size, pore volume and surface area allowed reactants easier accessibility to the $\mathrm{SO}_{3} \mathrm{H}$ sites leading to the higher efficiency of the starch catalyst.

Table 2. Textural properties of various solid acid catalysts.

\begin{tabular}{|c|c|c|c|c|c|c|}
\hline $\begin{array}{l}\text { Catalyst Derived } \\
\text { From }\end{array}$ & $\begin{array}{l}\text { S Content } \\
\text { wt. } \%\end{array}$ & $\begin{array}{c}\text { Total Acid Site } \\
\text { Density mmol/G }\end{array}$ & $\begin{array}{c}\mathrm{SO}_{3} \mathrm{H} \text { Acid Site } \\
\text { Density mmol/G }\end{array}$ & $\begin{array}{c}\text { Surface } \\
\text { Area } \mathrm{m}^{2} / \mathrm{g}\end{array}$ & $\begin{array}{l}\text { Average Pore } \\
\text { Volume } \mathrm{cm}^{3} / \mathrm{g}\end{array}$ & $\begin{array}{l}\text { Average Pore } \\
\text { Size nm }\end{array}$ \\
\hline D-Glucose & 4.7 & 1.6 & 1.47 & 4.1 & 0.44 & 4.0 \\
\hline Sucrose & 5.1 & 1.71 & 1.59 & 5.0 & 0.52 & 5.1 \\
\hline Cellulose & 5.4 & 1.82 & 1.68 & 5.7 & 0.65 & 6.4 \\
\hline Starch & 5.9 & 1.97 & 1.83 & 7.2 & 0.81 & 8.2 \\
\hline
\end{tabular}

Despite the inferior surface area of the carbohydrate-derived catalysts in comparison with the sulphated zirconia and niobic acid, the four prepared catalysts exhibited much higher esterification and transesterification activity. The starch catalyst in particular had an esterification and transesterification activity comparable to that of the concentrated $\mathrm{H}_{2} \mathrm{SO}_{4}$ (Figure 6). 


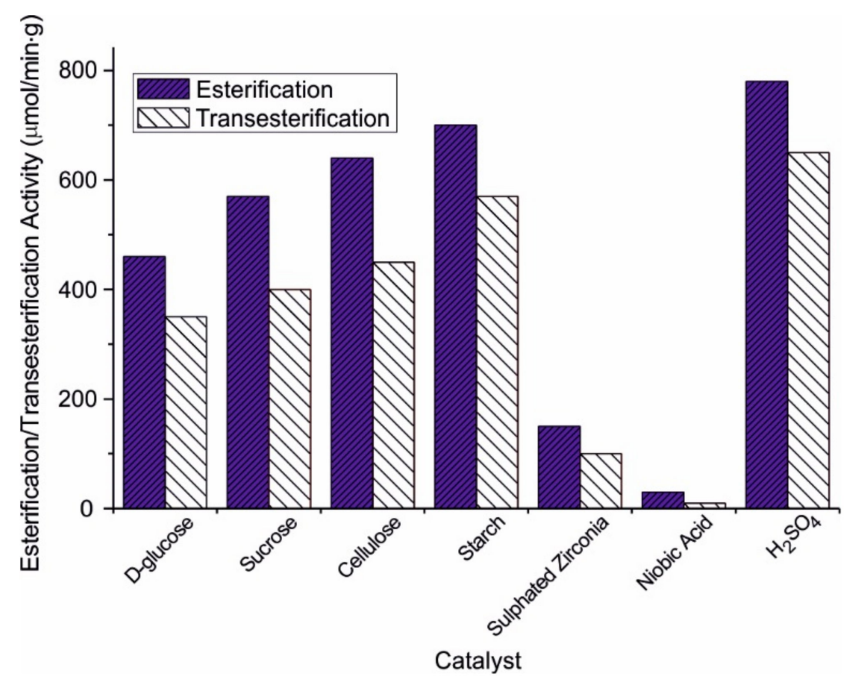

Figure 6. Activity of various catalysts for the esterification and transesterification reaction.

Following the initial experimentation that showed the effectiveness of the four carbohydrate-derived catalysts, Lou et al. [10] conducted a further experiment. The goal of which was to assess the effectiveness of the catalyst for the simultaneous esterification and transesterification of waste cooking oils (27.8 wt.\% FFA). The reaction was carried out at $80^{\circ} \mathrm{C}$ with a methanol: oil molar ratio of 20:1. As presented in Figure 7 the starch achieved the highest FAME yield in the shortest time of any of the catalyst.

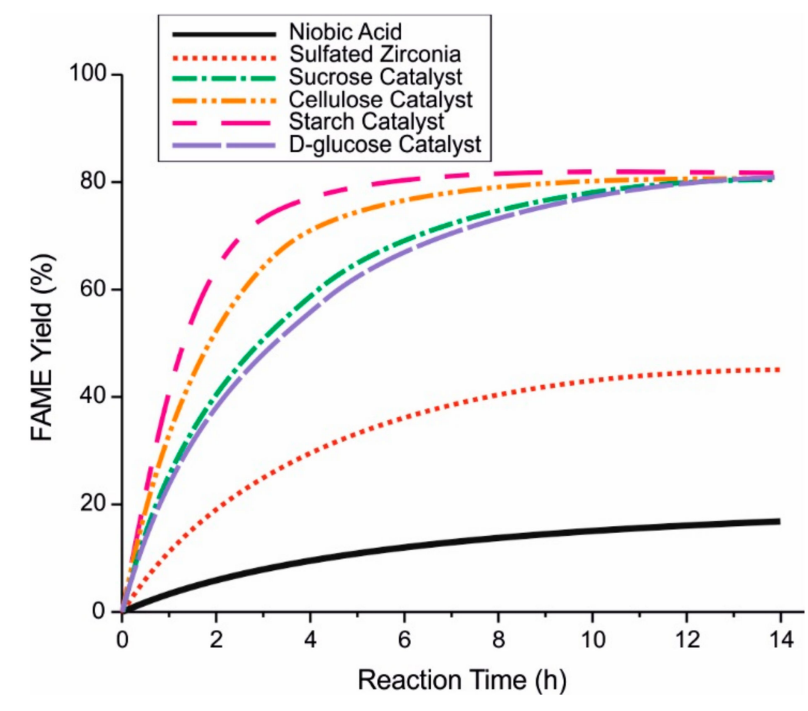

Figure 7. FAME yield for the various catalysts tested.

Through experimentation and assessing the return vs. the cost, it was determined that the optimal oil:methanol ratio was 30:1, and the catalyst loading was optimised at $10 \mathrm{wt} . \%$. The optimal reaction temperature and time was $80^{\circ} \mathrm{C}$ for $8 \mathrm{~h}$. Under these conditions, a yield of $92 \%$ was achieved. It was also determined that, the starch-derived catalyst retained $93 \%$ of its catalytic activity after fifty successive reuses.

Okamura et al. [40] completed a study on the effect of carbonisation temperature on the catalytic ability of a D-glucose catalyst. The D-glucose was carbonised at 300, 400,500 and $600{ }^{\circ} \mathrm{C}$. The acid content due to $\mathrm{SO}_{3} \mathrm{H}$ (which is representative of the catalytic performance) of the four D-glucose was compared, and the results are shown in Figure 8. 


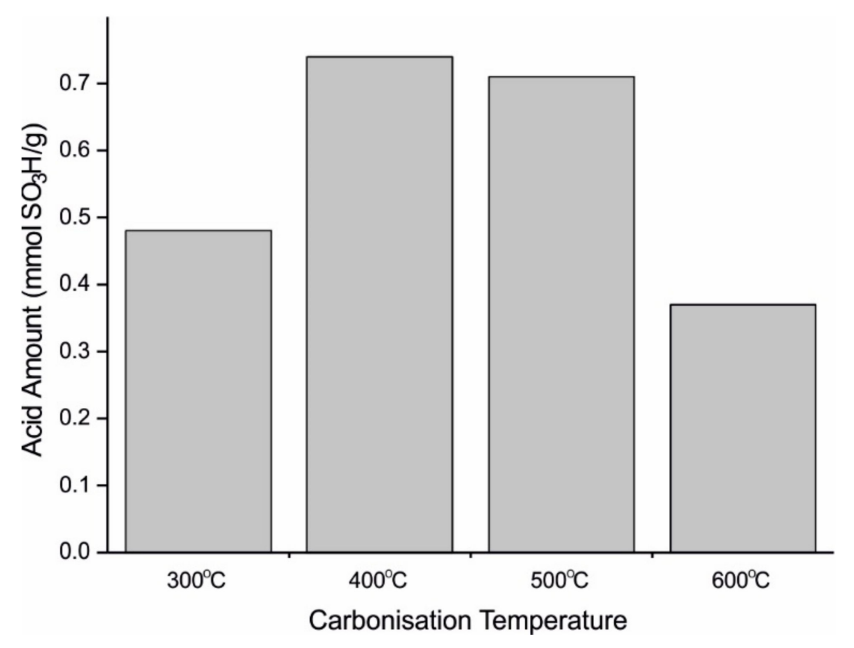

Figure 8. Acid content of D-glucose catalyst carbonised at different temperatures.

The acid content steadily increases with increasing carbonisation temperature up to $450{ }^{\circ} \mathrm{C}$. This temperature is the temperature used in the preparation of almost all the carbohydrate-derived CBASs discussed in this review. Beyond $450{ }^{\circ} \mathrm{C}$, the sulphur content and the catalytic performance of the D-glucose catalyst began to decrease dramatically. This effect can be summarised as follows; at lower carbonisation temperatures, small aromatic carbon sheets of 10-20 carbons are formed, as in Figure 3. The structural compositions of the biochars change with an increase in carbonisation temperature and give rise to a loss of aliphatic- $C$ moieties and a transformation of $\mathrm{C}$ compounds to mostly poly-condensed aromatic-C type structures [47]. The smaller polycyclic aromatic sheets formed at lower temperatures lead to a higher acid content as the $\mathrm{SO}_{3} \mathrm{H}$ groups join to the edges of the carbon sheets. Larger sheets formed at higher temperatures reduce the amount of potential locations for sulphonation to occur.

Interestingly, in the same study, a sample of the D-glucose carbonised at $400{ }^{\circ} \mathrm{C}$ was sulphonated with fuming sulphuric acid, and this catalyst exhibited twice the activity of the corresponding catalyst sulphonated with $\mathrm{H}_{2} \mathrm{SO}_{4}$.

\section{Biomass Precursors}

The conversion of biomass to effective and value-added catalytic material for biodiesel production makes use of a readily available and renewable feedstock that would usually be disposed of. The development of sulphonated carbon catalysts derived from waste biomass such as seed cake, nut husks and pyrolysis by-products will be the subject of this section.

Dawodu et al. [3] generated a sulphonated catalyst from the seed cake of Calophyllum Inophyllum (more commonly known as polanga). Polanga, an inedible tropical seed, was incompletely carbonised at $400{ }^{\circ} \mathrm{C}$ and the resulting powder was then sulphonated with concentrated $\mathrm{H}_{2} \mathrm{SO}_{4}$. SEM analysis of the material revealed large grains with irregular shapes and rough edges. The carbon was determined to be amorphous comprised of aromatic sheets in random orientation.

A one-step production of biodiesel (simultaneous esterification and transesterification) from polanga oil ( $15 \%$ FFA) was used to evaluate the catalytic ability of the sulphonated seed cake catalyst. The seed cake derived catalyst achieved a biodiesel yield of $99 \%$. The reusability of the catalyst was also evaluated, as presented in Figure 9. For three consecutive uses, the catalyst retained good reusability after the third use the catalytic activity began to decrease substantially. As observed by some researchers, a combination of sulphur leaching [48] and catalyst poisoning by glycol [3] is believed to be responsible for the loss of activity. 


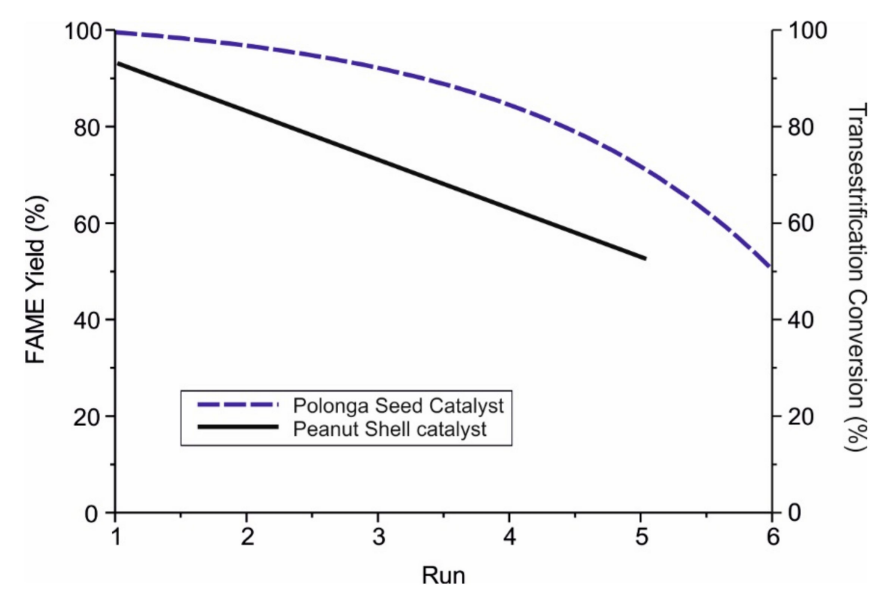

Figure 9. Reusability of polonga seed cake catalyst and peanut shell catalyst.

Vegetable oil and petroleum oil asphalt is another form of biomass that has received attention for its potential catalytic ability for biodiesel production. Shu et al. [49] prepared two solid acid catalysts by sulphonating vegetable and petroleum oil asphalt that was carbonised at $500-700{ }^{\circ} \mathrm{C}$. Following sulphonation the vegetable oil asphalt derived catalyst was found to have a loose irregular structure of large pores, conversely the petroleum asphalt catalyst exhibited little to no pores. The reason for the difference in morphology is believed to be due to the composition of the petroleum oil, consisting of the heaviest hydrocarbon non-metallic elements, which lead to a high degree of graphitisation following carbonisation, whereas vegetable oil asphalt is comprised of mainly straight chain aliphatic hydrocarbon polymers leading to a much lower level of graphitisation. The acid site density and the average pore size are presented in Table 3. The sulphur content and pore size of the vegetable oil asphalt derived catalyst were substantially higher than that of the petroleum oil asphalt.

Table 3. Sulphur content of oil asphalt catalysts.

\begin{tabular}{ccc}
\hline Catalyst & Sulphur wt.\% & Average Pore Size nm \\
\hline Vegetable oil asphalt & 7.1 & 43.9 \\
Petroleum oil asphalt & 3.6 & 2.2 \\
\hline
\end{tabular}

The attachment of $\mathrm{SO}_{3} \mathrm{H}$ groups to non-graphitic carbon is more favourable than graphitic carbon leading to a higher acid site density. As well as a higher acid site density, the sulphonated vegetable oil asphalt exhibited a larger average pore volume than the petroleum oil catalyst allowing the reactants easier access to acid sites.

Both the vegetable oil asphalt and the petroleum oil asphalt catalysts were assessed for their esterification and transesterification ability using a model waste oil (50\% cottonseed oil and 50\% oleic acid). A combined esterification and transesterification process was used with a catalyst loading of $0.3 \mathrm{wt} . \%$ and a molar ratio of methanol: oil of 20:9. The esterification was carried out at $140{ }^{\circ} \mathrm{C}$ for $2 \mathrm{~h}$, and following the esterification, the FAME and water formed in the first step were removed, fresh methanol was re-added to the reaction and the transesterification reaction was carried out at $220^{\circ} \mathrm{C}$ for $3 \mathrm{~h}$. The esterification and transesterification conversion are presented in Figure 10. 


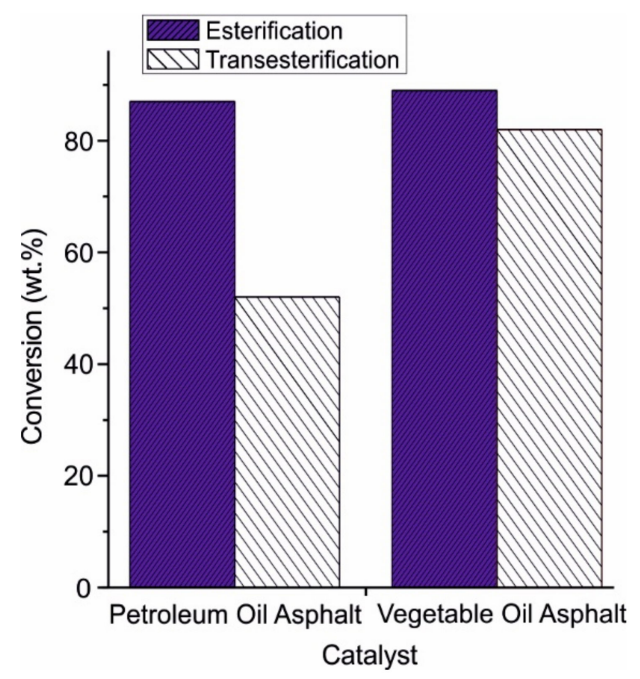

Figure 10. Esterification conversion for petroleum and vegetable asphalt catalysts.

The eco-friendly vegetable oil asphalt gave a significantly higher conversion of FFAs than either of the petroleum asphalt catalysts used. Similarly, under the stated reaction conditions the vegetable oil asphalt outperformed the petroleum oil asphalt in the transesterification reaction.

Biochar is obtained as a solid residue in the pyrolysis of biomass [50,51]. Biochar is of interest as a catalytic material for a wide variety of reasons such as; large surface area, high pore volume, long term stability, the potential for surface functional groups and low cost of production [51-54]. Depending on the heating rate during pyrolysis the biochar can be produced as the major component or as a by-product. Fast pyrolysis is used to produce bio-oil, and biochar is generated as a by-product of the reaction (about $15 \mathrm{wt} \%$ ), whereas slow pyrolysis with a lower heating rate favours the production of biochar giving a yield of $30-50 \mathrm{wt} \%[55,56]$.

Dehkhoda et al. [21] prepared two sulphonated biochar catalysts from woody biomass and examined their esterification and transesterification ability. The catalysts were prepared using two different methods. Method A: conc. $\mathrm{H}_{2} \mathrm{SO}_{4}$ was added to the biochar and heated; method $\mathrm{B}$ : the biochar was pre-treated with $7 \mathrm{M} \mathrm{KOH}$ to improve the porosity and surface area, and fuming $\mathrm{H}_{2} \mathrm{SO}_{4}$ was added to the treated biochar and heated.

Despite the lower surface area, catalyst B displayed a much higher sulphonic group density and total acidity than catalyst A (Table 4). Catalyst A showed little to no catalytic activity for the transesterification of canola oil in the presence of ethanol. However, the catalyst demonstrated good esterification ability when tested with waste vegetable oil. Catalyst B showed significantly better activity for the transesterification reaction due to the increased acid site density and in particular, the increased sulphonic group density as this is the only acid group strong enough to catalyse the transesterification process. Despite the increased activity of catalyst $B$ for the transesterification reaction, the maximum yield obtained was in the range of $10 \%$.

Table 4. Catalyst characterisation for method A and B.

\begin{tabular}{cccc}
\hline Catalyst & Surface Area $\mathbf{~ m}^{\mathbf{2}} \mathbf{g}$ & Sulphonic Group Density $\mathbf{~ m m o l} / \mathbf{g}$ & Total Acidity $\boldsymbol{\mu m o l} / \mathbf{g}$ \\
\hline Method A & 14.4 & 0.59 & 83 \\
Method B & 2.6 & 1.04 & 3200 \\
\hline
\end{tabular}

A further study was completed by Yu et al. [57] in which an improved sulphonated biochar catalyst was produced from woody biomass using a method similar to method B with the carbonisation of the biochar being carried out at a range of temperatures. As expected, the surface area decreased following sulphonation but as depicted in Table 5 the percentage decrease in surface area was drastically different 
for the catalysts carbonised at different temperatures. The catalyst carbonised at $450{ }^{\circ} \mathrm{C}$ showed the largest decrease in surface area, pore size, pore volume, and for the catalysts carbonised at 675 and $875^{\circ} \mathrm{C}$, the decrease in surface area, pore volume, and pore size was substantially lower. The reason for this is believed to be the elevated number of $\mathrm{C}-\mathrm{C}$ bonds when the biochar was carbonised at higher temperatures, the $\mathrm{C}-\mathrm{C}$ bond is more resistant to collapse leading to a lesser reduction in surface area, pore size and pore volume.

Table 5. Catalyst characterisation results for the various biochar catalysts.

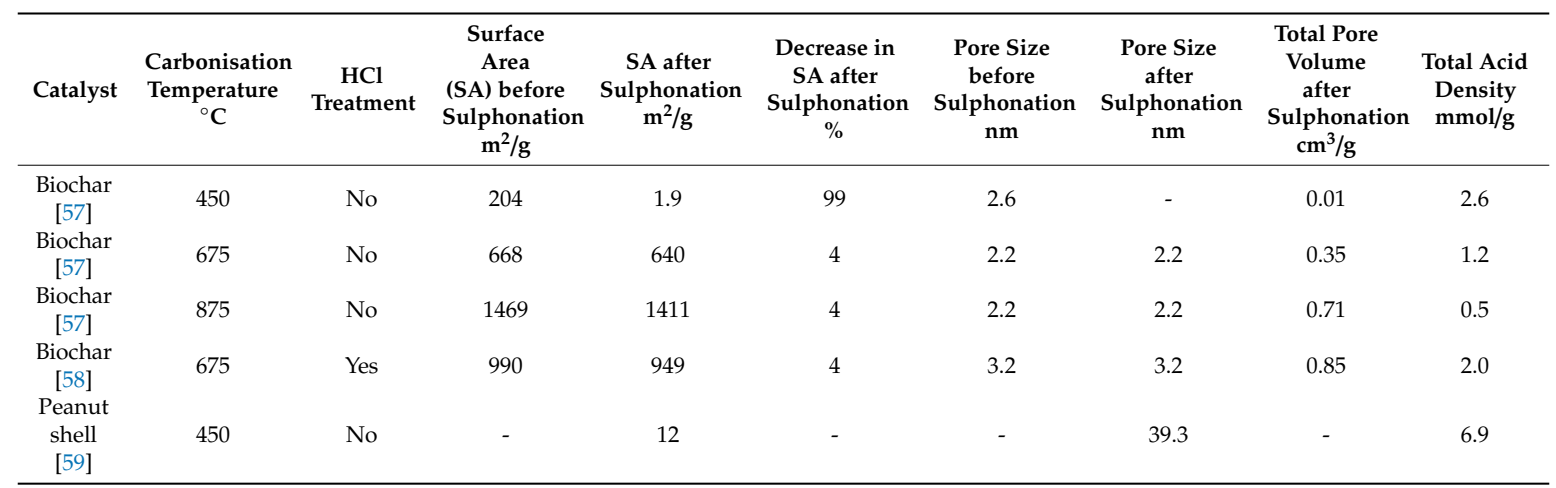

In contrast, the total acid density showed the opposite trend, with increasing carbonisation temperature and increasing degree of carbonisation, an increasing number of $\mathrm{C}-\mathrm{H}$ bonds are ruptured which in turn reduces the active acid sites available on the catalyst surface.

The transesterification of canola oil with methanol was used to evaluate the catalytic activity of the prepared catalyst. The yield of the three catalysts carbonised at three different temperatures can be seen in the Figure 11 . The catalyst carbonised at $675^{\circ} \mathrm{C}$ gave the highest yield of $18.9 \mathrm{wt} . \%$, and this catalyst provided the right balance between high surface area and high acid site density.

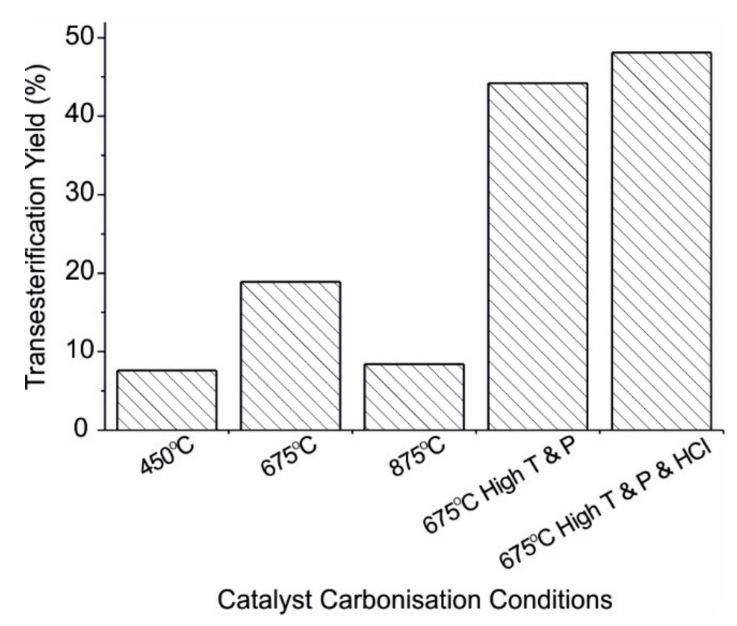

Figure 11. Transesterification yield of biochar catalyst.

A high pressure $(\mathrm{P})$ and temperature $(\mathrm{T})$ transesterification reaction was carried out at $150{ }^{\circ} \mathrm{C}$ and $1.52 \mathrm{MPa}$. The reaction was carried out for $3 \mathrm{~h}$ and the yield was $44 \%$, which is a marked improvement over the previous result presented in Figure 11. Upon evaluation of the reusability of the catalyst, it was found that the catalyst retained little to no activity $(0.9 \mathrm{wt} . \%)$ after the first run, and this was due to acid site leaching.

Dehkhoda and Ellis [58] completed a further investigation using the biochar carbonised at $675{ }^{\circ} \mathrm{C}$, where an improvement in the reusability of the catalyst was observed. The catalyst was prepared in a 
similar way to method B described previously with the addition of one extra step-before sulphonation, the catalyst was treated with $0.1 \mathrm{M} \mathrm{HCl}$. Catalyst characterisation results can be found in Table 5 .

A high pressure and temperature transesterification reaction was carried out at $150{ }^{\circ} \mathrm{C}$ and 1.5 MPa. The yield achieved was $48 \mathrm{wt} . \%$ presented in Figure 11, which is very promising for biodiesel production. The reaction yield only decreased by $8 \mathrm{wt} . \%$ upon reuse of the catalyst. This is a substantial improvement in the reusability compared with previous biochar catalysts.

Zeng et al. [59] produced a biochar-derived catalyst that was superior to all other catalysts discussed in terms of yield and reusability. Waste peanut shells were used as a biomass feedstock for a biochar catalyst. The waste peanut shells were carbonised at $450{ }^{\circ} \mathrm{C}$ and sulphonated with conc. $\mathrm{H}_{2} \mathrm{SO}_{4}$. Table 5 contains catalyst characterisation data. The transesterification of cottonseed oil was used to assess the catalytic performance of the peanut shell catalyst. The optimum reaction conditions were determined to be as follows; methanol: oil molar ratio of 9:1, and a reaction temperature of $85^{\circ} \mathrm{C}$. Under the stated reaction conditions, a yield of $90 \%$ was achieved.

The catalyst showed good stability. However, a gradual loss in activity was observed, following five runs the catalyst still maintained approx. $50 \%$ of its activity (Figure 9). Following the five runs, the catalyst was regenerated by treating with $1 \mathrm{M} \mathrm{H}_{2} \mathrm{SO}_{4}$ for $5 \mathrm{~h}$. The acid site density of the catalyst was initially $6.9 \mathrm{mmol} / \mathrm{g}$ following five uses the acid site density dropped to $3.4 \mathrm{mmol} / \mathrm{g}$. The catalyst was regenerated, and the acid site density again increased to $6.1 \mathrm{mmol} / \mathrm{g}$. The majority of the catalytic activity can be recovered using this regeneration process.

The waste peanut shell derived catalyst has been demonstrated to be a very attractive and viable catalyst option for biodiesel production. The feedstock is cheap, readily available and environmentally friendly, the resulting catalyst demonstrates high conversion and stability.

\section{Economic and Operating Condition Assessment}

Table 7 compares the different CBAS catalysts discussed in terms of cost per $\mathrm{kg}$, (the price given above does not represent bulk purchase prices and is for comparison purposes only) preparation conditions, operating conditions, reaction times, yield and reusability. Among the carbohydrate-derived catalysts, the carbonisation and sulphonation conditions are almost identical; carbonisation was carried out at between 400 and $450^{\circ} \mathrm{C}$ for up to $15 \mathrm{~h}$ for all of the carbohydrate-derived catalysts. Sulphonation conditions were typically $150-180^{\circ} \mathrm{C}$ for $10-15 \mathrm{~h}$ with conc. $\mathrm{H}_{2} \mathrm{SO}_{4}$ in the range of $10 \mathrm{~cm}^{3}$ per gram of catalyst. In some cases, fuming sulphuric acid was used, giving an improved catalytic performance. The starch and glucose derived catalysts were relatively more economical than their sucrose and cellulose counterparts. The starch catalyst prepared by Lou et al. [10] in particular shows excellent potential for commercial use. The catalytic activity of the starch catalyst is similar to that of concentrated $\mathrm{H}_{2} \mathrm{SO}_{4}$ for both the esterification and transesterification reactions. The starch-derived carbohydrate achieved the highest conversion and highest rate of reaction of any of the carbohydrate catalysts produced. The reusability of the catalyst is key to its application in industry, as this will reduce production costs. 
Table 6. Summary of operating conditions, performance and cost per $\mathrm{kg}$ for all catalysts discussed.

\begin{tabular}{|c|c|c|c|c|c|c|}
\hline Catalyst & $\begin{array}{l}\text { Cost Per kg }(\$) \\
\text { (Taken from Sigma } \\
\text { Aldrich) }\end{array}$ & $\begin{array}{l}\text { Carbonisation: } \\
\text { Temperature Time }\end{array}$ & Sulphonation Conditions & Reaction Conditions & $\begin{array}{l}\text { Yield: Esterification } \\
\text { Transesterification }\end{array}$ & Reusability \\
\hline D-glucose [46] & 39.2 & $\begin{array}{l}400^{\circ} \mathrm{C} \\
15 \mathrm{~h}\end{array}$ & $\begin{array}{l}\text { Conc. } \mathrm{H}_{2} \mathrm{SO}_{4} \\
150{ }^{\circ} \mathrm{C} \\
15 \mathrm{~h} \\
10 \mathrm{~mL} / \mathrm{g} \\
\end{array}$ & $\begin{array}{c}\text { Methanol:WCO weight ratio 1:1 } \\
10 \mathrm{wt} . \% \text { catalyst loading } \\
80^{\circ} \mathrm{C}\end{array}$ & Esterification $=90 \%$ & $\begin{array}{c}\text { Retains } 93 \% \text { of activity after } 50 \\
\text { successive runs }\end{array}$ \\
\hline D-glucose [39] & 39.2 & $\begin{array}{l}180^{\circ} \mathrm{C} \\
4 \mathrm{~h}\end{array}$ & $\begin{array}{l}\text { One step hydrothermal } \\
\text { carbonisation and } \\
\text { sulphonation }\end{array}$ & $\begin{array}{c}\text { Methanol:WCO molar ratio } 20: 1 \\
10 \mathrm{wt} . \% \text { catalyst loading } \\
80^{\circ} \mathrm{C}, 3 \mathrm{~h}\end{array}$ & Esterification $=95 \%$ & $\begin{array}{c}5 \text { repeated uses } 7 \% \text { increase in } \\
\text { FFAs }\end{array}$ \\
\hline Cellulose [41] & 196.0 & $\begin{array}{l}450^{\circ} \mathrm{C} \\
5 \mathrm{~h}\end{array}$ & $\begin{array}{l}\text { Fuming sulphuric acid } 180^{\circ} \mathrm{C} \\
\qquad 10 \mathrm{~h}\end{array}$ & $\begin{array}{c}\text { Esterification:oleic acid } \\
17 \mathrm{wt} \% \text { catalyst } \\
95^{\circ} \mathrm{C}, 4 \mathrm{~h} \\
\text { Transesterification: } \\
\text { Triolein } 130^{\circ} \mathrm{C}, 700 \mathrm{kPa}, 5 \mathrm{~h}\end{array}$ & $\begin{array}{c}\text { Esterification }=99.9 \% \\
\text { Transesterification }=98.1 \%\end{array}$ & $\begin{array}{l}\text { Esterification: No reduction in } \\
\text { activity after } 10 \text { uses } \\
\text { Transesterification: No } \\
\text { reduction in activity after four } \\
\text { uses }\end{array}$ \\
\hline D-glucose [10] & 39.2 & \multirow{4}{*}{$\begin{array}{l}400^{\circ} \mathrm{C} \\
15 \mathrm{~h}\end{array}$} & \multirow{4}{*}{$\begin{array}{l}\text { Conc. } \mathrm{H}_{2} \mathrm{SO}_{4} \\
150^{\circ} \mathrm{C} \\
15 \mathrm{~h}\end{array}$} & \multirow{4}{*}{$\begin{array}{c}\text { WCO }(27.8 \% \text { FFA }) \\
\text { Methanol:WCO molar ratio } 20: 1 \\
10 \mathrm{wt} \% \text { catalyst loading } \\
8 \mathrm{~h}, 80^{\circ} \mathrm{C}\end{array}$} & $\begin{array}{c}\text { Combined } \\
\text { Transesterification and } \\
\text { Esterification } 70 \%\end{array}$ & Not investigated \\
\hline Sucrose [10] & 93.4 & & & & $\begin{array}{l}\text { Combined } \\
\text { Transesterification and } \\
\text { Esterification }=72 \%\end{array}$ & Not investigated \\
\hline Cellulose [10] & 196.0 & & & & $\begin{array}{c}\text { Combined } \\
\text { Transesterification and } \\
\text { Esterification }=78 \%\end{array}$ & Not investigated \\
\hline Starch [10] & 31.9 & & & & $\begin{array}{c}\text { Combined } \\
\text { Transesterification and } \\
\text { Esterification }=92 \%\end{array}$ & $\begin{array}{l}\text { Retained } 93 \% \text { of catalytic } \\
\text { ability after } 50 \text { uses }\end{array}$ \\
\hline $\begin{array}{l}\text { Sulphonated seed } \\
\text { cake [3] }\end{array}$ & $\begin{array}{l}\text { By product of oil } \\
\text { extraction process. } \\
\text { Low-cost inedible oil }\end{array}$ & $\begin{array}{l}400^{\circ} \mathrm{C} \\
10 \mathrm{~h}\end{array}$ & $\begin{array}{l}\text { Conc. } \mathrm{H}_{2} \mathrm{SO}_{4} \\
150^{\circ} \mathrm{C} \\
10 \mathrm{~h}\end{array}$ & $\begin{array}{c}\text { Methanol:seed oil } \\
\text { weight ratio } 1: 1 \\
0.38 \mathrm{~g} \text { catalyst }(7.5 \mathrm{wt} \%) \\
180^{\circ} \mathrm{C}, 5 \mathrm{~h}\end{array}$ & $\begin{array}{c}\text { Combined } \\
\text { Transesterification and } \\
\text { Esterification }=99 \%\end{array}$ & $\begin{array}{l}\text { Begins to deteriorate after three } \\
\text { successive uses }\end{array}$ \\
\hline $\begin{array}{c}\text { Petroleum oil asphalt } \\
\text { [49] }\end{array}$ & $\begin{array}{l}\text { By-product of } \\
\text { petroleum industry }\end{array}$ & \multirow{2}{*}{$\begin{array}{l}500-700{ }^{\circ} \mathrm{C} \\
4-6 \mathrm{~h}\end{array}$} & \multirow{2}{*}{$\begin{array}{l}\text { Conc. } \mathrm{H}_{2} \mathrm{SO}_{4} \\
210^{\circ} \mathrm{C} \\
10 \mathrm{~h} \\
10 \mathrm{~mL} / \mathrm{g}\end{array}$} & \multirow{2}{*}{$\begin{array}{c}\text { Cottonseed oil:oleic acid molar ratio 1:1 } \\
\text { Methanol:oil molar ratio } 20: 9 \\
0.3 \mathrm{wt} . \% \text { catalyst loading } \\
140^{\circ} \mathrm{C} \text { Esterification } \\
220^{\circ} \mathrm{C} \text { Transesterification }\end{array}$} & $\begin{array}{c}\text { Esterification }=54 \% \\
\text { Transesterification }=87 \%\end{array}$ & Not investigated \\
\hline $\begin{array}{c}\text { Vegetable oil asphalt } \\
\text { [49] }\end{array}$ & $\begin{array}{l}\text { Low cost can be } \\
\text { produced from waste } \\
\text { oils and inedible oils }\end{array}$ & & & & $\begin{array}{c}\text { Esterification }=83 \% \\
\text { Transesterification }=89 \%\end{array}$ & Not investigated \\
\hline
\end{tabular}


Table 6. Cont

Table 7. Summary of operating conditions, performance and cost per $\mathrm{kg}$ for all catalysts discussed.

\begin{tabular}{|c|c|c|c|c|c|c|}
\hline Catalyst & $\begin{array}{l}\text { Cost Per kg (\$) } \\
\text { (Taken from Sigma } \\
\text { Aldrich) }\end{array}$ & $\begin{array}{l}\text { Carbonisation: } \\
\text { Temperature Time }\end{array}$ & Sulphonation Conditions & Reaction Conditions & $\begin{array}{l}\text { Yield: Esterification } \\
\text { Transesterification }\end{array}$ & Reusability \\
\hline Biochar A [21] & \multirow[t]{3}{*}{ Waste wood } & $\begin{array}{c}475^{\circ} \mathrm{C} \\
\text { Unknown time }\end{array}$ & $\begin{array}{l}\text { Conc. } \mathrm{H}_{2} \mathrm{SO}_{4} \\
150^{\circ} \mathrm{C} \\
24 \mathrm{~h} \\
10 \mathrm{~mL} / \mathrm{g}\end{array}$ & $\begin{array}{c}\text { Esterification: } \\
\text { Waste vegetable oil } 28: 1 \\
\text { Methanol:oil molar ratio } 15: 1 \\
5 \mathrm{wt} \% \text { catalyst } \\
60^{\circ} \mathrm{C}\end{array}$ & Esterification $=89 \%$ & Not investigated \\
\hline Biochar B [21] & & $\begin{array}{c}475^{\circ} \mathrm{C} \\
\text { Unknown time }\end{array}$ & $\begin{array}{c}\text { Fuming sulphuric acid } \\
150^{\circ} \mathrm{C} \\
5 \& 15 \mathrm{~h}\end{array}$ & $\begin{array}{c}\text { Transesterification } \\
\text { Methanol:oil molar ratio } 15: 1 \\
5 \mathrm{wt} \% \text { catalyst loading } \\
24 \mathrm{~h}, 65^{\circ} \mathrm{C} \\
\end{array}$ & Transesterification $=10 \%$ & Not investigated \\
\hline Biochar [57] & & $\begin{array}{l}450^{\circ} \mathrm{C} \\
675^{\circ} \mathrm{C} \\
875^{\circ} \mathrm{C} \\
4.5-7 \mathrm{~h}\end{array}$ & $\begin{array}{c}\text { Fuming sulphuric acid } \\
150^{\circ} \mathrm{C} \\
15 \mathrm{~h} \\
16.5 \mathrm{~mL} / \mathrm{g}\end{array}$ & $\begin{array}{l}\text { Methanol:canola oil molar ratio } 15: 1 \\
5 \mathrm{wt} \% \text { catalyst loading } \\
150^{\circ} \mathrm{C}, 3 \mathrm{~h}, 1.52 \mathrm{MPa}\end{array}$ & $\begin{array}{c}\text { Combined } \\
\text { Transesterification and } \\
\text { Esterification }=44.2\end{array}$ & $\begin{array}{l}\text { Loses almost all catalytic ability } \\
\text { after one use }\end{array}$ \\
\hline Biochar [21] & Waste product & $\begin{array}{c}675^{\circ} \mathrm{C} \\
\text { Unknown time }\end{array}$ & $\begin{array}{c}\text { Fuming sulphuric acid } \\
150^{\circ} \mathrm{C} \\
15 \mathrm{~h} \\
16.5 \mathrm{~mL} / \mathrm{g} \\
\end{array}$ & $\begin{array}{c}\text { Methanol:oil ( } 70 \% \text { canola } 30 \% \text { oleic acid) } \\
\text { molar ratio } 15: 1 \\
5 \mathrm{wt} \% \text { catalyst loading } \\
150{ }^{\circ} \mathrm{C}, 1.52 \mathrm{MPa}, 3 \mathrm{~h} \\
\end{array}$ & $\begin{array}{l}\text { Combined } \\
\text { Transesterification and } \\
\text { Esterification }=48.1\end{array}$ & $\begin{array}{l}\text { Reaction yield decreases by } 8 \% \\
\text { upon reuse of catalyst }\end{array}$ \\
\hline $\begin{array}{l}\text { Peanut shell biochar } \\
\text { [22] }\end{array}$ & $\begin{array}{l}\text { Waste product from } \\
\text { peanut industry }\end{array}$ & $\begin{array}{l}450^{\circ} \mathrm{C} \\
15 \mathrm{~h}\end{array}$ & $\begin{array}{l}\text { Conc. } \mathrm{H}_{2} \mathrm{SO}_{4} \\
200{ }^{\circ} \mathrm{C} \\
10 \mathrm{~h} \\
100 \mathrm{~mL} / \mathrm{g}\end{array}$ & $\begin{array}{c}\text { Refined cottonseed oil } \\
\text { Methanol:oil molar ratio 9:1 } \\
2 \mathrm{wt} \% \text { catalyst loading } \\
85^{\circ} \mathrm{C}, 2 \mathrm{~h}\end{array}$ & $\begin{array}{l}\text { Combined } \\
\text { Transesterification and } \\
\text { Esterification }=90.2 \%\end{array}$ & $\begin{array}{c}\text { Retains } 50 \% \text { of catalytic activity } \\
\text { after } 5 \text { runs. Easily regenerated } \\
\text { with } 1 \mathrm{M} \mathrm{H}_{2} \mathrm{SO}_{4}\end{array}$ \\
\hline
\end{tabular}


Biomass-derived catalysts have the advantage when it comes to economics, as the biochar is prepared from low-cost waste biomass feedstock. The catalyst synthesised from Calophyllum inophyllum seed cake by Dawodu et al. [3] exhibited excellent catalytic properties and demonstrated reusability for three successive runs. The seed cake catalyst promotes a reduced raw material cost, whereas the starch catalyst exhibits greater reusability and the reaction takes place at milder conditions. Further investigation is required to determine the most economical catalyst.

Of all the pyrolysis residue products that were investigated for their catalytic ability, the peanut shell biochar catalyst demonstrated the highest catalytic activity and the best reusability. The pyrolysis conditions used to produce this catalyst are mild in comparison with the other biochar catalysts discussed while the sulphonation conditions used are slightly harsher than those used in the starch or seed cake catalyst. Interestingly the ratio of concentrated $\mathrm{H}_{2} \mathrm{SO}_{4}$ to catalyst is twenty times higher than that used for the starch and seed cake catalyst. It is not known whether this ratio is necessary or whether it was just decided arbitrarily, and this may be an important factor to consider in the cost of production if it is a requirement. The catalysts derived from pyrolysis products generally suffer with reusability issues when compared with carbohydrate-derived catalysts.

In terms of the next steps for CBAS biodiesel catalysts, further investigation is required to determine which catalyst highlighted in the economic assessment is the most economically viable, taking cost of the raw material, preparation and operating conditions as well as yield and reusability into account. A study comparing their catalytic activity under identical reaction conditions would give comparable results between the catalysts allowing the optimal catalyst and reaction conditions to be chosen.

\section{Conclusions}

An ideal catalyst would have high acid site density, with a large amount of the acidity coming from $\mathrm{SO}_{3} \mathrm{H}$ functional groups, a large surface area, high stability leading to good reusability properties and a large average pore size and pore density. In terms of the carbohydrate-derived catalysts, the starch catalyst demonstrated the above properties to the greatest extent, delivering a high FAME yield and showing good reusability. The biomass catalyst prepared from seed cake showed excellent potential for commercial use, with a high yield and good reusability over three successive runs. The pyrolysis residue products typically suffer from poor reusability. However, the peanut shell biochar catalyst produced a very high FAME yield, while retaining a high proportion of its activity on subsequent runs, which was a marked improvement over the other biochar catalysts discussed.

One further area of study that may be of interest is the use of fuming sulphuric acid. In cases where fuming sulphuric acid was used, enhanced catalytic activity was observed. Investigation into the performance, reusability and economics of fuming sulphuric acid versus concentrated sulphuric acid under the same conditions is required to gain a clear picture of the advantages of one sulphonation method over the other.

Author Contributions: W.K. create the idea for the review and its structure, supervised the work, corrected the draft and implement changes and additional references. J.C. prepared the first draft and implemented corrections and novel ideas. All authors have read and agreed to the published version of the manuscript.

Funding: This research received no external funding.

Conflicts of Interest: The authors declare no conflict of interest.

\section{References}

1. $\quad$ IPCC. Global Warming of $1.5^{\circ} \mathrm{C}$; IPCC: Geneva, Switzerland, 2018.

2. Ma, F.; Hanna, M.A. Biodiesel production: A review Journal Series \#12109, Agricultural Research Division, Institute of Agriculture and Natural Resources, University of Nebraska-Lincoln. Bioresour. Technol. 1999, 70, 1-15. [CrossRef] 
3. Dawodu, F.A.; Ayodele, O.; Xin, J.; Zhang, S.; Yan, D. Effective conversion of non-edible oil with high free fatty acid into biodiesel by sulphonated carbon catalyst. Appl. Energy 2014, 114, 819-826. [CrossRef]

4. Borges, M.; Díaz, L. Recent developments on heterogeneous catalysts for biodiesel production by oil esterification and transesterification reactions: A review. Renew. Sustain. Energy Rev. 2012, 16, 2839-2849. [CrossRef]

5. Xie, W.; Li, H. Alumina-supported potassium iodide as a heterogeneous catalyst for biodiesel production from soybean oil. J. Mol. Catal. A Chem. 2006, 255, 1-9. [CrossRef]

6. Sulaiman, S. Overview of Catalysts in Biodiesel Production. J. Eng. Appl. Sci. 2016, 11, 439-448.

7. Ullah, F.; Dong, L.S.; Bano, A.; Peng, Q.Q.; Huang, J. Current advances in catalysis toward sustainable biodiesel production. J. Energy Inst. 2016, 89, 282-292. [CrossRef]

8. Renewable Energy Directive. Available online: https://ec.europa.eu/energy/en/topics/renewable-energy/ renewable-energy-directive/overview\#content-heading-0 (accessed on 5 December 2019).

9. Thangaraj, B.; Solomon, P.R.; Muniyandi, B.; Ranganathan, S.; Lin, L. Catalysis in biodiesel production-A review. Clean Energy 2018, 3, 2-23. [CrossRef]

10. Lou, W.-Y.; Zong, M.-H.; Duan, Z.-Q. Efficient production of biodiesel from high free fatty acid-containing waste oils using various carbohydrate-derived solid acid catalysts. Bioresour. Technol. 2008, 99, 8752-8758. [CrossRef] [PubMed]

11. Su, F.; Guo, Y. Advancements in solid acid catalysts for biodiesel production. Green Chem. 2014, 16, $2934-2957$. [CrossRef]

12. Konwar, L.J.; Boro, J.; Deka, D. Review on latest developments in biodiesel production using carbon-based catalysts. Renew. Sustain. Energy Rev. 2014, 29, 546-564. [CrossRef]

13. Munack, A. Books: Biodiesel-A comprehensive handbook. Martin Mittelbach, Claudia Remschmidt (Ed.). Biotechnol. J. 2006, 1, 102. [CrossRef]

14. Melero, J.; Iglesias, J.; Morales, G. Heterogeneous acid catalysts for biodiesel production: Current status and future challenges. Green Chem. 2009, 11, 1285-1308. [CrossRef]

15. Shah, S.; Sharma, S.; Gupta, M.N. Biodiesel Preparation by Lipase-Catalyzed Transesterification of Jatropha Oil. Energy Fuels 2004, 18, 154-159. [CrossRef]

16. Ejikeme, P.M.; Anyaogu, I.D.; Ejikeme, C.L.; Nwafor, N.P.; Egbuonu, C.A.C.; Ukogu, K.; Ibemesi, J.A. Catalysis in Biodiesel Production by Transesterification Processes-An Insight. J. Chem. 2010, 7, 1120-1132. [CrossRef]

17. Thangaraj, B.; Ramachandran, K.; Raj, S. Homogeneous Catalytic Transesterification of Renewable Azadirachta indica (Neem) Oil and Its Derivatives to Biodiesel Fuel via Acid/Alkaline Esterification Processes. Int. J. Renew. Energy Biofuels 2014, 2014, 11. [CrossRef]

18. Ghadge, S.; Raheman, H. Biodiesel Production from Mahua (Madhuca indica) Oil Having High Free Fatty Acids. Biomass Bioenergy 2005, 28, 601-605. [CrossRef]

19. Lee, A.F.; Bennett, J.A.; Manayil, J.C.; Wilson, K. Heterogeneous catalysis for sustainable biodiesel production via esterification and transesterification. Chem. Soc. Rev. 2014, 43, 7887-7916. [CrossRef]

20. Chua, S.Y.; Periasamy, L.A.P.; Goh, C.M.H.; Tan, Y.H.; Mubarak, N.M.; Kansedo, J.; Khalid, M.; Walvekar, R.; Abdullah, E.C. Biodiesel synthesis using natural solid catalyst derived from biomass waste-A review. J. Ind. Eng. Chem. 2020, 81, 41-60. [CrossRef]

21. Dehkhoda, A.M.; West, A.; Ellis, N. Biochar based solid acid catalyst for biodiesel production. Appl. Catal. A Gen. 2010, 382, 197-204. [CrossRef]

22. Leung, D.Y.C.; Wu, X.; Leung, M.K.H. A review on biodiesel production using catalyzed transesterification. Appl. Energy 2010, 87, 1083-1095. [CrossRef]

23. Mclaughlin, D.W. Land, Food, and Biodiversity. Conserv. Biol. 2011, 25, 1117-1120. [CrossRef] [PubMed]

24. Danielsen, F.; Beukema, H.; Burgess, N.D.; Parish, F.; Bruhl, C.A.; Donald, P.F.; Murdiyarso, D.; Phalan, B.; Reijnders, L.; Struebig, M.; et al. Biofuel plantations on forested lands: Double jeopardy for biodiversity and climate. Conserv. Biol. 2009, 23, 348-358. [CrossRef] [PubMed]

25. Demirbas, A. Importance of biodiesel as transportation fuel. Energy Policy 2007, 35, 4661-4670. [CrossRef]

26. Lotero, E.; Liu, Y.; Lopez, D.E.; Suwannakarn, K.; Bruce, D.A.; Goodwin, J.G. Synthesis of Biodiesel via Acid Catalysis. Ind. Eng. Chem. Res. 2005, 44, 5353-5363. [CrossRef]

27. Helwani, Z.; Othman, M.R.; Aziz, N.; Fernando, W.; Kim, J. Technologies for production of biodiesel focusing on green catalytic techniques: A review. Fuel Process. Technol. 2009, 90, 1502-1514. [CrossRef] 
28. Arzamendi, G.; Campo, I.; Arguiñarena, E.; Sánchez, M.; Montes, M.; Gandía, L.M. Synthesis of biodiesel with heterogeneous $\mathrm{NaOH} /$ alumina catalysts: Comparison with homogeneous NaOH. Chem. Eng. J. 2007, 134, 123-130. [CrossRef]

29. Kouzu, M.; Kasuno, T.; Tajika, M.; Sugimoto, Y.; Yamanaka, S.; Hidaka, J. Calcium oxide as a solid base catalyst for transesterification of soybean oil and its application to biodiesel production. Fuel 2008, 87, 2798-2806. [CrossRef]

30. Vitiello, R.; Li, C.Z.; Russo, V.; Tesser, R.; Turco, R.; Di Serio, M. Catalysis for esterification reactions: A key step in the biodiesel production from waste oils. Rend. Lincei Sci. Fis. Nat. 2017, 28, 117-123. [CrossRef]

31. Balajii, M.; Niju, S. Biochar-derived heterogeneous catalysts for biodiesel production. Environ. Chem. Lett. 2019, 17, 1447-1469. [CrossRef]

32. Hara, M. Biomass conversion by a solid acid catalyst. Energy Environ. Sci. 2010, 3, 601-607. [CrossRef]

33. Venkat Reddy, C.R.; Oshel, R.; Verkade, J.G. Room-Temperature Conversion of Soybean Oil and Poultry Fat to Biodiesel Catalyzed by Nanocrystalline Calcium Oxides. Energy Fuels 2006, 20, 1310-1314. [CrossRef]

34. Mahlia, T.M.I.; Syazmi, Z.; Mofijur, M.; Abas, A.E.P.; Bilad, M.R.; Ong, H.C.; Silitonga, A.S. Patent landscape review on biodiesel production: Technology updates. Renew. Sustain. Energy Rev. 2020, 118, 9. [CrossRef]

35. Di Serio, M.; Tesser, R.; Casale, L.; D’Angelo, A.; Trifuoggi, M.; Santacesaria, E. Heterogeneous Catalysis in Biodiesel Production: The Influence of Leaching. Top. Catal. 2010, 53, 811-819. [CrossRef]

36. D'Cruz, A.; Kulkarni, M.G.; Meher, L.C.; Dalai, A.K. Synthesis of Biodiesel from Canola Oil Using Heterogeneous Base Catalyst. J. Am. Oil Chem. Soc. 2007, 84, 937-943. [CrossRef]

37. Descorme, C.; Gallezot, P.; Geantet, C.; George, C. Heterogeneous Catalysis: A Key Tool toward Sustainability. ChemCatChem 2012, 4, 1897-1906. [CrossRef]

38. Sivasamy, A.; Cheah, K.Y.; Fornasiero, P.; Kemausuor, F.; Zinoviev, S.; Miertus, S. Catalytic applications in the production of biodiesel from vegetable oils. ChemSusChem 2009, 2, 278-300. [CrossRef]

39. Nata, I.F.; Putra, M.D.; Irawan, C.; Lee, C.-K. Catalytic performance of sulfonated carbon-based solid acid catalyst on esterification of waste cooking oil for biodiesel production. J. Environ. Chem. Eng. 2017, 5, 2171-2175. [CrossRef]

40. Okamura, M.; Takagaki, A.; Toda, M.; Kondo, J.N.; Domen, K.; Tatsumi, T.; Hara, M.; Hayashi, S. Acid-Catalyzed Reactions on Flexible Polycyclic Aromatic Carbon in Amorphous Carbon. Chem. Mater. 2006, 18, 3039-3045. [CrossRef]

41. Hara, M. Biodiesel Production by Amorphous Carbon Bearing $\mathrm{SO}_{3} \mathrm{H}, \mathrm{COOH}$ and Phenolic OH Groups, a Solid Bronsted Acid Catalyst. Top. Catal. 2010, 53, 805-810. [CrossRef]

42. Mo, X.; Lotero, E.; Changqing, L.; Liu, Y.; Goodwin, J. A Novel Sulfonated Carbon Composite Solid Acid Catalyst for Biodiesel Synthesis. Catal. Lett. 2008, 123, 1-6. [CrossRef]

43. Escobar, J.C.; Lora, E.S.; Venturini, O.J.; Yáñez, E.E.; Castillo, E.F.; Almazan, O. Biofuels: Environment, technology and food security. Renew. Sustain. Energy Rev. 2009, 13, 1275-1287. [CrossRef]

44. Leung, D.Y.C.; Guo, Y. Transesterification of neat and used frying oil: Optimization for biodiesel production. Fuel Process. Technol. 2006, 87, 883-890. [CrossRef]

45. Liu, R.; Wang, X.; Zhao, X.; Feng, P. Sulfonated ordered mesoporous carbon for catalytic preparation of biodiesel. Carbon 2008, 46, 1664-1669. [CrossRef]

46. Zong, M.-H.; Duan, Z.-Q.; Lou, W.-Y.; Smith, T.J.; Wu, H. Preparation of a sugar catalyst and its use for highly efficient production of biodiesel. Green Chem. 2007, 9, 434-437. [CrossRef]

47. Kwapinski, W.; Byrne, C.M.P.; Kryachko, E.; Wolfram, P.; Adley, C.; Leahy, J.J.; Novotny, E.H.; Hayes, M.H.B. Biochar from Biomass and Waste. Waste Biomass Valoriz. 2010, 1, 177-189. [CrossRef]

48. Arumugamurthy, S.S.; Sivanandi, P.; Pandian, S.; Choksi, H.; Subramanian, D. Conversion of a low value industrial waste into biodiesel using a catalyst derived from brewery waste: An activation and deactivation kinetic study. Waste Manag. 2019, 100, 318-326. [CrossRef]

49. Shu, Q.; Nawaz, Z.; Gao, J.; Liao, Y.; Zhang, Q.; Wang, D.; Wang, J. Synthesis of biodiesel from a model waste oil feedstock using a carbon-based solid acid catalyst: Reaction and separation. Bioresour. Technol. 2010, 101, 5374-5384. [CrossRef]

50. Tang, J.; Zhu, W.; Kookana, R.; Katayama, A. Characteristics of biochar and its application in remediation of contaminated soil. J. Biosci. Bioeng. 2013, 116, 653-659. [CrossRef] 
51. Xiong, X.; Yu, I.K.M.; Cao, L.; Tsang, D.C.W.; Zhang, S.; Ok, Y.S. A review of biochar-based catalysts for chemical synthesis, biofuel production, and pollution control. Bioresour. Technol. 2017, 246, 254-270. [CrossRef]

52. Severini, F.; Leahy, J.J.; Kwapinski, W. Heterogeneous Char Based Solid Acid Catalysts from Brown Bin Waste to Create a Green Process for the Production of Butyl Butyrate. Waste Biomass Valoriz. 2017, 8, 2431-2441. [CrossRef]

53. Severini, F.; Flannelly, T.; O’Nolan, D.; Leahy, J.J.; Kwapinski, W. Development of heterogeneous acid catalysts produced from the carbonization of Miscanthus $x$ giganteus for the esterification of butyric acid to butyl butyrate with n-butanol. J. Chem. Technol. Biotechnol. 2016, 91, 2076-2084. [CrossRef]

54. Wang, Y.T.; Delbecq, F.; Kwapinski, W.; Len, C. Application of sulfonated carbon-based catalyst for the furfural production from D-xylose and xylan in a microwave-assisted biphasic reaction. Mol. Catal. 2017, 438, 167-172. [CrossRef]

55. Cheng, F. Preparation and Application of Biochar-Based Catalysts for Biofuel Production. Catalysts 2018, 8, 346. [CrossRef]

56. Liu, W.-J.; Jiang, H.; Yu, H.-Q. Development of Biochar-Based Functional Materials: Toward a Sustainable Platform Carbon Material. Chem. Rev. 2015, 115, 12251-12285. [CrossRef]

57. Yu, J.T.; Dehkhoda, A.M.; Ellis, N. Development of Biochar-based Catalyst for Transesterification of Canola Oil. Energy Fuels 2011, 25, 337-344. [CrossRef]

58. Dehkhoda, A.M.; Ellis, N. Biochar-based catalyst for simultaneous reactions of esterification and transesterification. Catal. Today 2013, 207, 86-92. [CrossRef]

59. Zeng, D.; Liu, S.; Gong, W.; Wang, G.; Qiu, J.; Chen, H. Synthesis, characterization and acid catalysis of solid acid from peanut shell. Appl. Catal. A Gen. 2014, 469, 284-289. [CrossRef]

(C) 2020 by the authors. Licensee MDPI, Basel, Switzerland. This article is an open access article distributed under the terms and conditions of the Creative Commons Attribution (CC BY) license (http://creativecommons.org/licenses/by/4.0/). 